\title{
PLAGIAT DAN PEMBAJAKAN \\ KARYA CIPTA DALAM HAK KEKAYAAN INTELEKTUAL ${ }^{*}$
}

\author{
Nahrowi ${ }^{1}$ \\ Permalink: https://www.academia.edu/9997804
}

\begin{abstract}
Plagiarism and Piracy on copyrights Work in Intellectual Property Rights. Indonesia already has constitution on copy rights work, i.e. Constitution No. 6 Year 1982, Constitution No. 7 Year 1987, Constitution No. 12 Year 1997 and Constitution No. 19 Year 2002. Constitution on copyrights was made to protect sources of arts and cultures, also to develop Indonesian intellectual ability, so that healthy and fair competitions are guaranteed for national development. However, plagiarism and piracy acts emerge. Moreover, plagiarism and piracy acts are done not only in Indonesia but also in the world involving respected such as reporters, academicians, professors, distinguished people, and reputable musicians or even famous companies.
\end{abstract}

Keywords: copyrights, plagiarism, piracy

\begin{abstract}
Abstrak: Plagiat dan Pembajakan Karya Cipta Dalam Hak Kekayaan Intelektual. Indonesia telah memiliki Undang-undang Hak Cipta, yaitu; Undang-undang Nomor 6 Tahun 1982, UU Nomor 7 Tahun 1987, UU Nomor 12 Tahun 1997, dan yang terakhir adalah UU Nomor 19 Tahun 2002. Undang-undang Hak Cipta dibuat untuk melindungi kekayaan seni dan budaya, serta pengembangan kemampuan intelektual masyarakat Indonesia agar terdapat iklim persaingan usaha yang sehat yang diperlukan dalam melaksanakan pembangunan nasional. Akan tetapi, kasus plagiat dan pembajakan karya cipta semakin banyak bermunculan. Lebih parah lagi, kasus plagiat dan pembajakan karya cipta bukan hanya terjadi di Indonesia bahkan di luar Indonesia dan menimpa para tokoh terkemuka; wartawan, akademisi, professor, penerima penghargaan kelas dunia dan musisi ternama, dan perusahaanperusahaan ternama.
\end{abstract}

Kata Kunci: hak cipta, karya cipta, plagiat dan pembajakan

* Diterima tanggal naskah diterima: 14 Juli 2014, direvisi: 29 Oktober 2014, disetujui untuk terbit: 17 November 2014.

${ }^{1}$ Fakultas Syariah dan Hukum UIN Jakarta. Jl. Ir. H. Juanda No. 95 Ciputat Jakarta. E-mail: nahrowi@gmail.com. 


\section{Pendahuluan}

Hak Cipta adalah bagian dari hak atas Kekayaan Intelektual, yang termasuk HaKI adalah: Hak Cipta, Hak Paten, Merk, Rahasia Dagang, Waralaba, Lisensi dan Royalti, Desain Industri, Tata Letak (Topografi) Sirkuit Terpadu, Varietas Tanaman dan Rekayasa genetika, Internet dan Domain Names.

Adapun perundang-undangan yang mengaturnya adalah: 1). Undangundang Nomor 12 Tahun 1997 dan Undang-undang Nomor 19 Tahun 2002 tentang Hak Cipta, 2). UU No. 13/1997 dan UU No. 14/2001 tentang Paten, 3). UU No. 14/1997 dan UU No. 15/2001 tentang Merek, 4). UU No. 30/2000 tentang Rahasia Dagang, 5). UU No. 31/2000 tentang Desain Industri, 6). UU No. 32/2000 tentang Tata Letak Sikuit Terpadu, 7). UU No. 20/2000 tentang Varietas Tanaman, 8). PP No. 16/1997 tentang Waralaba (Franchise), 9). UU No. 5/1999 tentang Anti Monopoli dan Persaingan Tidak Sehat, 10). UU No. 8/1999 tentang Perlindungan Konsumen.

Indonesia telah ikut serta dalam pergaulan masyarakat dunia dengan menjadi anggota dalam Agreement Establishing the World Trade Organization (Persetujuan Pembentukan Organisasi Perdagangan Dunia) yang mencakup pula Agreement on Trade Related Aspects of Intellectual Properti Right (Persetujuan tentang Aspek-Aspek Dagang Hak Kekayaan Intelektual), selanjutnya disebut TRIPS, melalui UU Nomor 7 Tahun 1994, selain itu Indonesia juga meratifikasi Berne Convention for the Protection of Artistic and Literary Works (Konvensi Berne tentang Perl;indungan Karya Seni dan Sastra) melalui Keputusan Presiden Nomor 18 Tahun 1997 dan World Intellectual Property Organization Copyrights Treaty (Perjanjian Hak Cipta WIPO), selanjutnya disebut WCT, melalui Keputusan Presiden Nomor 19 Tahun 1997. ${ }^{2}$ Melalui keikutsertaan dalam Lembaga Internasional atau meratifikasi Perjanjian Internasional sebenarnya Indonesia secara instrumen perundangundangan sudah sangat mendukung tegaknya perlindungan dan penghargaan terhadap Hak Kekayaan Intelektual.

Setelah melalui beberapakali perubahan UUHC, dan yang terbaru adalah UU Nomor 19 Tahun 2002, menurut pasal 2 ayat (1) UU Nomor 19 Tahun 2002 tantang Hak Cipta (selanjutnya disebut UUHC), memberikan pengertian tentang Hak Cipta, yaitu: "Hak eksklusif bagi pencipta atau pemegang hak cipta untuk mengumumkan atau memperbanyak ciptaannya yang timbul secara otomatis setelah suatu ciptaan dilahirkan tanpa mengurangi pembatasan menurut peraturan perundang-undangan yang berlaku”. Hak Cipta terdiri atas hak ekonomi (economic rights) dan hak moral (moral rights). Hak Ekonomi adalah hak untuk mendapatkan manfaat ekonomi atas ciptaan serta produk terkait terkait. Hak moral adalah hak yang melekat pada diri pencipta atau pelaku yang tidak dapt dihilangkan atau dihapus tanpa alasan apapun, walaupun Hak Cipta atau Hak terkait telah dialihkan.

Karena ciptaan-ciptaan ini dilindungi hak cipta sebagai hak ekslusif, ciptaan-ciptaan ini menjadi hak yang semata-mata diperuntukkan bagi pencipta

\footnotetext{
${ }^{2}$ Penjelasan Umum UUHC Paragraf ke-2.
} 
atau pihak lain yang diperbolehkan memanfaatkan hak tersebut dengan seizin pencipta. Kegiatan mengumumkan atau memperbanyak diartikan sebagai kegiatan-kegiatan dengan menerjemahkan, mengadaptasi, mengaransemen, mengalihwujudkan, menyiarkan, merekam, mengimpor atau mengekspor, memamerkan atau mempertunjukkan kepada publik, dan mengkomunikasikan ciptaan kepada publik melalui sarana apapun.

Secara tradisional, Hak Cipta telah diterapkan ke dalam buku-buku, tetapi sekarang Hak Cipta telah meluas dan mencakup perlindungan atas karya sastra, drama, karya musik dan artistik, termasuk rekaman suara, penyiaran suara film dan televisi dan program komputer. Hak Cipta bagi kebanyakan karya cipta berlaku untuk selama hidup pencipta dan 50 tahun setelah meninggalnya si pencipta. Bagi negara-negara berkembang, fakta bahwa negaranegara maju mengontrol hak cipta atas sebagian besar piranti lunak, produkproduk video dan musik terkenal dengan apa yang dinamakan sebagai budaya global, tidak dapat dihindarkan lagi telah mengakibatkan permasalahan di bidang pembajakan dan impor paralel. Pembuat UU dan para hakim menemui kesulitan dalam mengikuti langkah kemajuan teknologi (termasuk internet) yang mengakibatkan pengkopian menjadi lebih mudah dan lebih cepat. ${ }^{3}$

Sebagai tindakan pencegahan atau pemberantasan pembajakan terhadap karya cipta, UUHC menyediakan perangkat hukum pada pasal 72 yang berisi 7 ayat, berupa denda dan/atau penjara terhadap perbuatan tanpa hak/izin terhadap karya cipta, yaitu: 1). Memperbanyak atau mengumumkan, 2). Menyiarkan atau menyewakan, 3). Memamerkan, mengedarkan atau menjual, 4). Mengubah, mengganti atau meniadakan, 5). Merusak atau membuat tidak berfungsi dengan denda serendah-rendahnya satu juta rupiah dan setinggi-tingginya lima miliar rupiah dan/atau pidana penjara serendahrendahnya satu bulan dan paling lama tujuh tahun.

\section{Pengertian Plagiat dan Pembajakan}

Plagiat adalah penjiplakan atau pengambilan karangan (pendapat dsb) orang lain dan menjadikannya seolah-olah karangan (pendapat dsb) sendiri, misal menerbitkan karya tulis orang lain atas nama dirinya sendiri; jiplakan. ${ }^{4}$ Plagiat juga mempunyai arti sebagai perbuatan secara sengaja atau tidak sengaja dalam memperoleh atau mencoba memperoleh kredit atau nilai untuk suatu karya ilmiah, dengan mengutip sebagian atau seluruh karya dan/atau karya ilmiah pihak lain yang diakui sebagai karya ilmiahnya, tanpa menyatakan sumber secara tepat dan memadai. ${ }^{5}$ Pelaku plagiat disebut Plagiator, sedangkan sifat pelaku untuk memplagiat disebut Plagiarisme.

Felicia Utorodewo dkk dalam bukunya "Bahasa Indonesia: Sebuah Pengantar Penulisan Ilmiah”, digolongkan sebagai tindakan plagiarisme adalah: 2006, h. 6-7.

${ }^{3}$ Tim Lindsey dkk, Hak Kekayaan Intelektual-Suatu Pengantar, Bandung: Alumni,

${ }_{5}^{4}$ Pusat Bahasa Departemen Pendidikan Nasional, KBBI,1997, h. 75.

5 Bab I ayat (1) Permendiknas Nomor 17 Tahun 2010 tentang Pencegahan dan Penanggulangan Plagiat. 
(1) Mengakui tulisan orang lain sebagai tulisan sendiri,

(2) Mengakui gagasan orang lain sebagai gagasan sendiri,

(3) Mengakui temuan orang lain sebagai temuan sendiri,

(4) Mengakui karya kelompok sebagai kepunyaan atau hasil sendiri,

(5) Menyajikan tulisan yang sama dalam kesempatan yang berbeda tanpa menyebutkan asal-usulnya,

(6) Meringkas dan memfrasekan (mengutip tak langsung) tanpa menyebutkan sumbernya, dan

(7) Meringkas dan memfrasekan dengan menyebut sumbernya, tetapi rangkaian kalimat dan pilihan katanya masih terlalu sama dengan sumbernya,

(8) Menggunakan tulisan orang lain secara mentah, tanpa memberikan tanda jelas (misalnya dengan menggunakan tanda kutip atau blok alinea yang berbeda) bahwa teks tersebut diambil persis dari tulisan lain,

(9) Mengambil gagasan orang lain tanpa memberikan anotasi yang cukup tentang sumbernya.

Pembajakan atau yang disebut Piracy,adalah penyalinan atau penyebaran secara tidak sah atas obyek ciptaan yang dilindungi undangundang. Obyek ciptaan adalah hasil setiap karya pencipta yang menunjukkan keasliannya dalam lapangan ilmu pengetahuan, seni dan sastra. Menurut pasal; 12 UUHC, ciptaan yang dilindungi adalah: a). Buku program komputer, pamflet, perwajahan (lay out) karya tulis yang diterbitkan, dan semua hasil karya tulis lain; b). Ceramah, kuliah, pidato, dan ciptaan lain yang sejenis dengan itu; c). Alat peraga yang dibuat untuk kepentingan pendidikan dan ilmu pengetahuan; d). Lagu atau musik dengan atau tanpa teks; e). Drama atau drama musikal, tari, koreografi, pewayangan dan pantomim; f). Seni rupa dalam segala bentuk seperti seni lukis, gambar, seni ukir, seni kaligrafi, seni pahat, seni patung, kolase, dan seni terapan; g). Arsitektur; h). Peta; i). Seni batik; j). Fotografi; k). Sinematografi; 1). Terjemahan, tafsir, saduran, bunga rampai, databese, dan karya lain dari hasil pengalihwujudan.

\section{Faktor-faktor yang Mempengaruhi Maraknya Plagiat dan Pembajakan Karya Cipta}

Dalam prosiding tentang HaKI dari Lokakarya terbatas masalah Kepailitan dan wawasan Hukum Bisnis lainnya dieditori Emmy Yuhassarie: 2004, bahwa faktor-faktor yang mempengaruhi maraknya pembajakan karya cipta adalah: (1) faktor sosial ekonomi, (2) faktor sosial budaya, (3) perbandingan harga, (4) pendidikan, (5) rendahnya sanksi hukum. Sanksi hukum yang diterapkan terhadap pembajakan hanya diterapkan pada penjual barang bajakan, belum diterapkan pada konsumen yang membeli barang bajakan. Selama ini penegakkan hukum di bidang hak Cipta belum berlaku secara menyeluruh. Apabila mengacu pada UUHC, maka sanksi yang ditekankan kepada pembajak hanya bersifat denda semata dan belum mengarah pada sanksi yang bersifat pemidaan.

Ada beberapa pertanyaan yang diajukan Para penulis hak Kekayaan intelektual- Suatu pengantar, yaitu: (1) Mengapa melindungi HaKI, (2) Kritik- 
kritik terhadap HaKI, kesimpulan jawaban adalah: HaKI perlu dilindungi karena (a) HaKI merupakan hak-hak alami yang perlu dilindungi berupa kejujuran dan keadilan, Sebagai perbuatan yang tidak jujur dan tidak adil jika seseorang mencuri usaha seseorang tanpa mendapatkan terlebih dahulu persetujuannya, (b) perlindungan reputasi, (b) dorongan dan imbalan dari inovasi dan penciptaan. Adapun kritik-kritik terhadap HaKI adalah: (a) HaKI sebagai tindakan monopoli, sementara di negara-negara berkembang hak milik tetap harus mempunyai fungsi sosial dan menjadi milik bersama, sehingga hak monopoli dalam HaKI dapat mengakibatkan harga tinggi, (b) perusahaanperusahaan mungkin tidak sepenuhnya memanfaatkan ciptaan-ciptaan penting mereka, (c) royalti akan mengakibatkan harga yang lebih tinggi dan akan mencegah aliran ilmu pengetahuan. ${ }^{6}$

\section{Menghindari Plagiat dan Pembajakan Karya Cipta Dengan Mengetahui Pembatasan-pembatasan Hak Cipta}

Pembatasan terhadap Hak Cipta tertuang dalam pasal 13-18, pasal 13 UUHC menyatakan: "Tidak ada Hak Cipta atas: (a) hasil rapat terbuka lembaga-lembaga negara; (b) peraturan perundang-undangan; (c) pidato kenegaraan atau pidato pejabat Pemerintahan; (d) putusan pengadilan atau penetapan hakin; atau (e) keputusan badan arbitrase atau keputusan badanbadan sejenis lainnya. Pasal 14, menyatakan tidak dianggap sebagai pelanggaran hak cipta;

1. Penggunaan Ciptaan pihak lain untuk kepentingan pendidikan, penelitian, penulisan karya ilmiah, penyusunan laporan, penulisan kritik atau tinjauan suatu masalah dengan tidak merugikan kepentingan yang wajar dari Pencipta;

2. Kedua; Pengambilan Ciptaan pihak lain, baik seluruhnya maupun sebagian, guna keperluan pembelaan di dalam atau di luar Pengadilan;

3. Ketiga; Pengambilan Ciptaan pihak lain, baik seluruhnya maupun sebagian, guna keperluan; ceramah yang semata-mata untuk tujuan pendidikan dan ilmu pengetahuan; atau pertunjukan atau pementasan yang tidak dipungut bayaran dengan ketentuan tidak merugikan kepentingan yang wajar dari Pencipta;

4. Keempat, Perbanyakan suatu Ciptaan bidang ilmu pengetahuan, seni, dan sastra dalam huruf braille guna keperluan para tunanetra, kecuali jika Perbanyakan itu bersifat komersial;

5. Kelima, Perbanyakan suatu Ciptaan selain Program Komputer, secara terbatas dengan cara atau alat apa pun atau proses yang serupa oleh perpustakaan umum, lembaga ilmu pengetahuan atau pendidikan, dan pusat dokumentasi yang nonkomersial semata mata untuk keperluan aktivitasnya;

6. Keenam, perubahan yang dilakukan berdasarkan pertimbangan pelaksanaan teknis atas karya arsitektur, seperti Ciptaan bangunan;

\footnotetext{
${ }^{6}$ Tim Lindsey dkk, Hak Kekayaan Intelektual-Suatu Pengantar, h. 13-18.
} 
7. Ketujuh, pembuatan salinan cadangan suatu Program Komputer oleh pemilik Program Komputer yang dilakukan semata mata untuk digunakan sendiri.

\section{Pasal 16}

1. Untuk kepentingan pendidikan, ilmu pengetahuan, serta kegiatan penelitian dan pengembangan, terhadap Ciptaan dalam bidang ilmu pengetahuan dan sastra, Menteri setelah mendengar pertimbangan Dewan Hak Cipta dapat:

a. mewajibkan Pemegang Hak Cipta untuk melaksanakan sendiri penerjemahan dan/atau Perbanyakan Ciptaan tersebut di wilayah Negara Republik Indonesia dalam waktu yang ditentukan;

b. mewajibkan Pemegang Hak Cipta yang bersangkutan untuk memberikan izin kepada pihak lain untuk menerjemahkan dan/atau memperbanyak Ciptaan tersebut di wilayah Negara Republik Indonesia dalam waktu yang ditentukan dalam hal Pemegang Hak Cipta yang bersangkutan tidak melaksanakan sendiri atau melaksanakan sendiri kewajiban sebagaimana dimaksud dalam huruf a;

c. menunjuk pihak lain untuk melakukan penerjemahan dan/atau Perbanyakan Ciptaan tersebut dalam hal Pemegang Hak Cipta tidak melaksanakan kewajiban sebagaimana dimaksud dalam huruf b.

2. Kewajiban untuk menerjemahkan sebagaimana dim aksud pada ayat (1), dilaksanakan setelah lewat jangka waktu 3 (tiga) tahun sejak diterbitkannya Ciptaan di bidang ilmu pengetahuan dan sastra selama karya tersebut belum pernah diterjemahkan ke dalam bahasa Indonesia.

3. Kewajiban untuk memperbanyak sebagaimana dimaksud pada ayat (1) dilaksanakan setelah lewat jangka waktu:

a. 3 (tiga) tahun sejak diterbitkannya buku di bidang matematika dan ilmu pengetahuan alam dan buku itu belum pernah diperbanyak di wilayah Negara Republik Indonesia;

b. 5 (lima) tahun sejak diterbitkannya buku di bidang ilmu sosial dan buku itu belum pernah diperbanyak di wilayah Negara Republik Indonesia;

c. 7 (tujuh) tahun sejak diumumkannya buku di bidang seni dan sastra dan buku itu belum pernah diperbanyak di wilayah Negara Republik Indonesia.

4. Penerjemahan atau Perbanyakan sebagaimana dimaksud pada ayat (1) hanya dapat digunakan untuk pemakaian di dalam wilayah Negara Republik Indonesia dan tidak untuk diekspor ke wilayah Negara lain.

5. Pelaksanaan ketentuan sebagaimana dimaksud pada ayat (1) 
huruf $\mathrm{b}$ dan huruf $\mathrm{c}$ disertai pemberian imbalan yang besarnya ditetapkan dengan Keputusan Presiden.

6. Ketentuan tentang tata cara pengajuan Permohonan untuk menerjemahkan dan/atau memperbanyak sebagaimana dimaksud pada ayat (1), ayat (2), ayat (3), dan ayat (4) diatur lebih lanjut dengan Keputusan Presiden.

\section{Pasal 17}

Pemerintah melarang Pengumuman setiap Ciptaan yang bertentangan dengan kebijaksanaan Pemerintah di bidang agama, pertahanan dan keamanan Negara, kesusilaan, serta ketertiban umum setelah mendengar pertimbangan Dewan Hak Cipta.

\section{Pasal 18}

1. Pengumuman suatu Ciptaan yang diselenggarakan oleh Pemerintah untuk kepentingan nasional melalui radio, televisi dan/atau sarana lain dapat dilakukan dengan tidak meminta izin kepada Pemegang Hak Cipta dengan ketentuan tidak merugikan kepentingan yang wajar dari Pemegang Hak Cipta, dan kepada Pemegang Hak Cipta diberikan imbalan yang layak.

2. Lembaga Penyiaran yang mengumumkan Ciptaan sebagaimana dimaksud pada ayat (1) berwenang mengabadikan Ciptaan itu semata-mata untuk Lembaga Penyiaran itu sendiri dengan ketentuan bahwa untuk penyiaran selanjutnya, Lembaga Penyiaran tersebut harus memberikan imbalan yang layak kepada Pemegang Hak Cipta yang bersangkutan.

\section{Mengetahui Cara Pendeteksian Plagiat}

Pasal 1 ayat (1) Permendikanas Nomor 17 Tahun 2010 , pada intinya mengarahkan sebagai teknik mendeteksi plagiat adalah:

(1) Adanya perbedaan internal dalam isi teks, seperti dalam gaya, ejaan, tanda baca, penggunaan font, cetak miring, bahasa, tata bahasa dan konstruksinya,

(2) Tugas yang diserahkan kualitasnya lebih baik atau bentuknya berbeda (misalnya ujaran bahasanya) dengan apa yang biasanya mahasiswa yang bersangkutan hasilkan,

(3) Terdapat ketidak konsistenan internal dalam hal perujukan apakah di teks utama, pustaka acuan atau keduanya,

(4) Adanya penghilangan sumber tertentu yang mestinya harus muncul,

(5) Pernyataan yang tidak didukung oleh bagian teks lainnya, misalnya, "seperti kita dapati dalam tabel di bawah ini" sementara tabelnya sendiri tidak ada, 
(6) Tugas yang disampaikan tidak sesuai dengan apa yang ditugaskan, kualitasnya lebih rendah dari apa yang diminta, dan

(7) Perujukan yang tidak memadai atau tak sejalan dengan rincian yang muncul di dalam naskah.

\section{Plagiat secara Perdata} sebagai berikut:

Dalam KUHPerdata plagiat dapat dikaitkan dengan pasal-pasal Pasal 529 KUHPer

Pasal 548 KUHPer

Pasal 557 KUHPer

Pasal 570 KUHPer

Pasal 572 KUHPer

Pasal 584 KUHPer

Pasal 612 KUHPer

Bila diusut ulang maka hak milik benda tersebut bermula dari kepemilikan buku dan bukan kepemilikan karya. Hal inilah yang dalam pasal 542 KUHPer disebut dengan bezit atau penguasaan benda. Dan dari penguasaan benda tersebut, pada pasal 548 menyatakan bahwa dengan itikad baik, bezit memberi hak pada pemegang barang yang berupa :

1. Untuk dianggap sebagai pemilik barang untuk sementara, sampai saat barang itu dituntut kembali di muka Hakim;

2. Untuk dapat memperoleh hak milik atas barang itu karena lewat waktu;

3. Untuk menikmati segala hasilnya sampai saat barang itu dituntut kembali di muka hakim;

4. Untuk mempertahankan besitnya bila ia digangu dalam memegangnya, atau dipulihkan kembali besitnya bila ía kehilangan besitnya itu.

Dalam kasus ini bezit atau penguasaan benda diberikan kepada pembeli atas benda yang dibelinya, yang dalam hal ini berupa buku. Tetapi tidak dengan isi buku tersebut yang merupakan hak milik pengarang atau disebut juga dengan hak cipta. Berkaitan dengan penguasaan benda tersebut, pada pasal 557 KUHPer disebutkan "Tuntutan untuk mempertahankan bezit dapat diajukan terhadap orang-orang yang mengganggu pemegang bezit dalam memegang besit itu, bahkan terhadap pemilik barang itu, tetapi tanpa mengurangi hak pemilik itu untuk mengajukan tuntutan berdasarkan hak miliknya.

Bila bezit itu diperoleh dari pinjam pakai, dengan pencurian atau kekerasan, maka pemegang besit tidak bisa mengajukan tuntutan untuk dipertahankan dalam besitnya terhadap orang dari siapa besit itu diperolehnya atau dari orang dari siapa besit itu diambil." Pada pembahasan diatas, dapat kita simpulkan bahwa karya atau ide yang tertulis pada buku tersebut secara otomatis penguasaannya mengikuti penguasaan terhadap bendanya. Tetapi kepemilikannya tidak mengikuti penguasaan tersebut.

Pada pasal 570 dikemukakan tentang definisi hak milik dan batasanbatasannya. Yang mana hak milik adalah "Hak milik adalah hak untuk menikmati suatu barang secara lebih leluasa dan untuk berbuat terhadap barang 
itu secara bebas sepenuhnya, asalkan tidak bertentangan dengan undangundang atau peraturan umum yang ditetapkan oleh kuasa yang berwenang dan asal tidak mengganggu hak-hak orang lain; kesemuanya itu tidak mengurangi kemungkinan pencabutan hak demi kepentingan umum dan penggantian kerugian yang pantas, berdasarkan ketentuan-ketentuan perundang-undangan.”

Pada pasal 572 KUHPer dinyatakan bahwa hak milik harus dianggap bebas. Sehingga pemilik dapat menggunakannya dengan bebas dan dengan kekuasaan seluas-luasnya dengan tanpa melanggar ketentuan-ketentuan yang berlaku dan batasan-batasannya. Maka, barang siapa menyatakan mempunyai hak kepemilikan atas barang orang lain, harus membuktikan hak itu. Kepemilikan atas duplikat ide tersebut yang berupa buku atau sesuatu yang dapat dimiliki oleh orang lain dengan berupa benda, merupakan kepemilikan pembeli yang menjadi pemilik sah buku yang diperolehnya dengan cara-cara yang dibenarkan oleh hukum. Maka ia dapat menggunakan buku tersebut secara maksimal, sesuai dengan ketentuan hukum. Tetapi kepemilikan isi buku tersebut adalah milik pengarang yang mana ia melahirkan atau memunculkan idenya yang berupa tulisan tersebut.

Mengenai penduplikatan isi buku atau ide tersebut, dengan berdasarkan pada perjanjian antara penulis dengan pihak penerbit buku, maka hak publikasi atau membuat salinan isi buku tersebut menjadi hak milik perusahaan penerbit. Maka bila ada pihak lain yang bermaksud menggandakan isi buku tersebut harus mendapatkan ijin dari pihak pemegang lisensi penggandaan buku atau suatu karya tersebut. Cara-cara bagaimana perolehan hak milik, diatur dalam pasal 548 KUHPer ini.

Dalam pasal 3 ayat (1) UU nomor 19 Tahun 2002 tentang hak cipta, hak cipta dinyatakan sebagai benda bergerak. Maka hak cipta dapat dimiliki dan dialihkan sebagaimana hak milik. Pada dasarnya tulisan merupakan benda yang tak bertubuh maka penyerahannya dilakukan dengan penyerahan yang nyata oleh atau atas nama pemilik. Hal ini terdapat dalam pasal 612 KUHPer. Yang dengan jelas bahwa penyerahan tulisan tersebut kepada orang lain atau ditulis ulang dalam bentuk lain harus mencantumkan nama pemilik tulisan, yang dengan kata lain harus mencantumkan nama penulis atau pengarang karya tulis tersebut.

Pada pasal 2 ayat (1) UUHC, diterangkan tentang definisi hak cipta secara khusus yang isinya bahwa Hak Cipta merupakan hak eksklusif bagi Pencipta atau Pemegang Hak Cipta untuk mengumumkan atau memperbanyak Ciptaannya, yang timbul secara otomatis setelah suatu ciptaan dilahirkan tanpa mengurangi pembatasan menurut peraturan perundang-undangan yang berlaku. Yang mana pengalihan hak cipta, dalam hal penggandaan suatu karya tulis atau kekayaan intelektual lainnya, dapat dilakukan dengan pemberian lisensi atau perijinan kepada suatu pihak tertentu yang hal ini diatur dalam suatu kesepakatan antara pihak pemegang hak milik dengan pihak lain yang akan menerima pengalihan hak cipta tersebut. Maka jelaslah bahwa penggandaan atau duplikasi menjadi wewenang pihak penerima hak cipta. Dan barang siapa yang hendak menggandakan seluruh atau sebagian dari karya yang 
hak ciptanya dalam penguasaan suatu pihak tertentu, maka harus mendapatkan izin dari pihak pemegang lisensi hak cipta tersebut.

Pada pasal 3 ayat (2) UUHC, dijelaskan mengenai macam-macam cara pengalihan hak cipta. Salah satunya sudah disebutkan pada pembahasan sebelumnya, yaitu dengan suatu perikatan atau perjanjian. Pada pasal 12 dijabarkan tentang macam-macam hak cipta yang dilindungi oleh hokum dan ketentuan-ketentuannya. Dan isi pasal tersebut adalah :

1) Dalam Undang-undang ini Ciptaan yang dilindungi adalah Ciptaan dalam bidang ilmu pengetahuan, seni, dan sastra, yang mencakup:

1. Buku, Program Komputer, pamflet, perwajahan (lay out) karya tulis yang diterbitkan, dan semua hasil karya tulis lain;

2. Ceramah, kuliah, pidato, dan Ciptaan lain yang sejenis dengan itu;

3. Alat peraga yang dibuat untuk kepentingan pendidikan dan ilmu pengetahuan;

4. Lagu atau musik dengan atau tanpa teks;

5. Drama atau drama musikal, tari, koreografi, pewayangan, dan pantomim;

6. Seni rupa dalam segala bentuk seperti seni lukis, gambar, seni ukir, seni kaligrafi, seni pahat, seni patung, kolase, dan seni terapan;

7. Arsitektur;

8. Peta;

9. Seni batik;

10. Fotografi;

11. Sinematografi;

12. Terjemahan, tafsir, saduran, bunga rampai, database, dan karya lain dari hasil pengalihwujudan.

2) Ciptaan sebagaimana dimaksud dalam huruf 1 dilindungi sebagai Ciptaan tersendiri dengan tidak mengurangi Hak Cipta atas Ciptaan asli.

3) Perlindungan sebagaimana dimaksud pada ayat (1) dan ayat (2), termasuk juga semua Ciptaan yang tidak atau belum diumumkan, tetapi sudah merupakan suatu bentuk kesatuan yang nyata, yang memungkinkan Perbanyakan hasil karya itu.

Dengan berdasarkan pada pasal 612 KUHPer, maka penggandaan barang tanpa mencantumkan nama pemilik adalah suatu tindak pelanggaran terhadap hak cipta. Tetapi dalam UUHC pasal 15, pemerintah Indonesia membuat suatu pengecualian terhadap tindakan ini. Dan isi dari pasal tersebut adalah : "Dengan syarat bahwa sumbernya harus disebutkan atau dicantumkan, tidak dianggap sebagai pelanggaran Hak Cipta:

a. Penggunaan Ciptaan pihak lain untuk kepentingan pendidikan, penelitian, penulisan karya ilmiah, penyusunan laporan, penulisan kritik atau tinjauan suatu masalah dengan tidak merugikan kepentingan yang wajar dari Pencipta;

b. Pengambilan Ciptaan pihak lain, baik seluruhnya maupun sebagian, guna keperluan pembelaan di dalam atau di luar Pengadilan;

c. pengambilan Ciptaan pihak lain, baik seluruhnya maupun sebagian, guna keperluan: 
i. ceramah yang semata-mata untuk tujuan pendidikan dan ilmu pengetahuan; atau

ii. pertunjukan atau pementasan yang tidak dipungut bayaran dengan ketentuan tidak merugikan kepentingan yang wajar dari Pencipta.

d. Perbanyakan suatu Ciptaan bidang ilmu pengetahuan, seni, dan sastra dalam huruf braille guna keperluan para tunanetra, kecuali jika Perbanyakan itu bersifat komersial;

e. Perbanyakan suatu Ciptaan selain Program Komputer, secara terbatas dengan cara atau alat apa pun atau proses yang serupa oleh perpustakaan umum, lembaga ilmu pengetahuan atau pendidikan, dan pusat dokumentasi yang non komersial semata-mata untuk keperluan aktivitasnya;

f. Perubahan yang dilakukan berdasarkan pertimbangan pelaksanaan teknis atas karya arsitektur, seperti Ciptaan bangunan;

g. Pembuatan salinan cadangan suatu Program Komputer oleh pemilik Program Komputer yang dilakukan semata-mata untuk digunakan sendiri.”

Maka sudah jelas bahwa tindak pengutipan suatu karya tulis tanpa mencantumkan nama pemilik hak cipta atas karya tersebut adalah suatu pelanggaran atas hak cipta. Mengenai kepemilikan karya tersebut adalah menjadi hak milik pemegang hak cipta. Dan karya turunan yang merupakan hasil jiplakan tanpa identitas sumber idenya, akan kembali kepada pemilik hak cipta sebatas bagian yang merupakan kutipan tersebut. Dan apabila merugikan pihak pemegang hak cipta, maka pihak tersebut dapat melakukan wanprestasi atas tindakan pengkutipan tersebut. ${ }^{7}$

\section{Penutup}

Adapun kesimpulan dalam tulisan makalah ini adalah:

1. Dalam Hak Cipta terdapat dua hak yang melekat, yaitu Hak Ekonomi dan Hak Moral.

2. Kasus plagiat lebih mengarah kepada pelanggaran terhadap Hak Moral Pencipta.

3. Penegakan terhadap Hak Cipta lebih mengutamakan kepada pelaku pelanggaran yang membuat dan yang mendistribusikan ketimbang pengguna perseorangan.

4. Plagiat di Indonesia berbeda dengan kasus plagiat di luar negeri yang tidak hanya terbatas pada karya ilmiah dan obyek hak cipta lainnya tetapi juga kepada Hak Paten dan Merk.

7 diakses dari http://grifalenwestreenen.wordpress.com/2012/03/31/analisis-hukumperdata-pada-kasus-plagiat/, tanggal 26 Maret 2013. 
238 - Nahrowi; Plagiat dan Pembajakan Karya Cipta Dalam Hak Kekayaan Intelektual

\section{Pustaka Acuan}

Pusat Bahasa Departemen Pendidikan Nasional, KBBI,1997.

Tim Lindsey dkk, Hak Kekayaan Intelektual-Suatu Pengantar, Bandung: Alumni, 2006.

Permendiknas Nomor 17 Tahun 2010 tentang Pencegahan dan Penanggulangan Plagiat.

http://grifalenwestreenen.wordpress.com/2012/03/31/analisis-hukum-perdatapada-kasus-plagiat/, tanggal 26 Maret 2013. 